\title{
Systematic Review: Effect of Strangle on Health of Equine Animals and its Prevention
}

\author{
Tagesu Abdisa* \\ Jimma University, Ethiopia
}

Submission: May 02, 2018; Published: July 02, 2018

*Corresponding author: Tagesu Abdisa, Jimma University, School of Veterinary Medicine, Jimma, Oromia, Ethiopia, Tel: 251933681407; Email: abdisatagesu@gmail.com/tagesua@hotmail.com

\begin{abstract}
Strangle is an infectious and highly contagious respiratory disease of equine which have great impact on the health of equnines. It is caused by streptococcus equi sub sp. equi, a gram positive bacterium in irregular shaped cocci that forms long chain. Strangles occurs worldwide mostly in horses and rarely in donkey and mules. The outbreak of strangle is frequently seen on racing stable, riding and breeding farms when the infection is introduced by new arrivals that are often carrier. Strangle disease affects mostly young horses and outbreak can occur at any time of the year but, most likely to happen in cold weather. The severity of the clinical presentation depends on age, previous infections, vaccination and stabling conditions. Strangle can be transmitted to other equine animals buy direct and in direct ways. The causative agent of strangle, S. equi var equi have great variety of virulence factors that interact with host tissues and components, and favour bacteria colonization and growth. The pathogenesis of strangle disease is begin with nasopharyngeal infection with S. equi var equi follows contact with a shedding carrier horse. The after the bacteria begin to multiply in lymph nodes.

The clinical sign which observed from diseased animal are like complete anorexia, depression, fever, serous nasal discharge which becomes copious and mucopurulent, loss of body condition and enlargement of Sub mandibular lymph node with subsequent dyspnea. The diagnosis of strangle disease is based on clinical sign and laboratory finding including bacterial culture, PCR and serology. The treatment of diseased animal in the early stage is usually effective, but it is difficult to treat which are in chronic stage of disease. The best way to prevent an outbreak of strangle disease is by keeping hygiene and giving vaccination for equine animals. Therefore, the objective of this manuscript is to overview general fact of strangle disease and how it effect on the health of equine animal. And also it give enough information for the future study on the strangle disease in species of equine animals.
\end{abstract}

Keywords: Strangle; Diagnosis; Equine; S. Equi subsp, Submandibular lymph node

\section{Introduction}

Equines are the animals which grouped under odd toed foot animals in the order Perissodactyla, they are known by serving the community by transportation, and also in some country their meat has been taken as food [1]. Equine animals are an estimated $80 \%$ of the world equine population, $90 \%$ million equine, are found in the developing world, including $97 \%$ of mules, $96 \%$ of donkeys and $60 \%$ of horses and most of these will be used for work [2]. It is reported that two million horses, 0.36 million mules and seven million donkeys comprise the working equid population in Ethiopia and this represents the largest population of equine in Africa [3]. The current reported data revealed that Ethiopia has the largest equine population in Africa and eighth in the world. She possesses 2.16 million horses, 8.44 million donkeys and 0.41 million mules [4]. Equines play an important role in the transport of farm product, fodder, fire wood, agricultural inputs and construction and waste material.
Working equids have a direct impact on the lives of rural people by reducing the transport burdens of water, fuel, wood and goods [5], transporting people and in some areas for agricultural purposes [5-7]. Although, Ethiopia has large number of Equines, the productivity of these animals is decreased by the infectious and non-infectious disease.

The most common diseases of equine animals are like respiratory disease, lymphatic system disease, and GIT disease. Respiratory tract infections are considered the major problem of equine worldwide. Strangles is an infectious and highly contagious respiratory bacterial disease of equine caused by Streptococcus equi [8]. The respiratory disease of equine animals can be classified into contagious upper respiratory tract disease (viral and bacterial); non contagious respiratory tract disease (functional abnormalities of larynx); Infectious lower respiratory tract disease (bacterial pneumonia) and non 
infectious lower respiratory tract disease [9]. Upper respiratory tract infection in horses is common and can be caused by viral, fungal, and bacterial pathogens. These include equine influenza virus, equine herpes viruses, Aspergillus species, and Lancefield group C Streptococcus species $[10,11]$.

Out of different disease of upper respiratory tract infection, strangle is the most common upper respiratory disease which effect on health of Equine animals. Strangles is an infectious, contagious disease of Equidae characterized by abscessation of the lymphoid tissue of the upper respiratory tract. The bacterium Streptococcus equi subsp. equi (S. equi) is the causative agent of the important and highly contagious upper respiratory disease "strangles" in horses and other equids [12,13]. Historically, strangles got its name because affected horse was sometimes suffocated from large infected lymph nodes that obstructed their upper airway. The name strangle was named by Bourgelat in 1791 [14].

Strangle disease is very contagious which have high morbidity and low mortality rate. Severity of clinical disease varies with classical clinical manifestation of an upper respiratory tract infection which includes acute dyspnea, dysphasia, internal lymph node abscessation and immune mediated responses $[14,15]$. After incubation period ranged from 3 days to 2 weeks from exposure to causative agent, then infective organisms shed in nasal discharges and pus from opened lymph nodes [16]. The occurrence of strangle disease was recorded in young foals compared to adult one. The $S$. equi var equi easily spreads from infected to susceptible horses through contaminated water and other fomites [8]. The diagnosis of strangle in horse can be undergone by different methods, bacteriological culture of nasal swabs, nasal washes and aspirated pus from abscesses remains gold standard for $S$. equi $[17,18]$. In the recent time, serological test has been developed to identify equine animals that exposed to strangle disease $[19,20]$. The major significances importance of strangle disease in equine animals are death of animals, disruption of the management of commercial horse establishments, the time to treat affected horse and esthetic unpleasantness of running nose and draining abscesses [2]. Control and prevention of strangle disease can be achieved by keeping animals in hygienic condition and vaccination [21]. The main critical perspective of this manuscript is that to give concept about strangle, its impact, diagnoses and treatment also the methods how to control spreading of this disease in equine animals. To sum up, strangle is the most common contagious disease which disrupt healthy of horse that push economy of developing country into negative sides.

\section{Strangle Disease and its Infact in Equine Animals Etiology}

Strangle disease has been studied in different journals and the name was coined because of the enlarged lymph nodes that made affected horse suffocate by obstructed air ways [14].The causative agent of strangle disease is Streptococcus equi subsp. equi, a gram positive bacterium in irregular shaped cocci that forms long chain; it belongs to Lancefield group C [22]. The main characteristic of streptococcus bacteria are facultative anaerobic catalase negative, oxidase negative, non-motile and hemolytic [22]. The colony of streptococcus bacteria after culture looks like honey colored, mucoid colonies on blood agar, it makes wide zone of hemolysis ( beta hemolysis) on blood agar $[22,23]$. S. equi is belongs to group of pyogennic streptococci and it is biochemically differentiated from other beta hemolytic group of streptococcus Lancefield C by its inability to ferment sorbitol, lactose and trehalose [22]. S.equi is highly resistant to phagocytosis due to the presence of hyaluronic acid capsule, SeM binds fibrinogen and different IgG subclasses which masks binding sites for complement factors (C3b) [24] S. equi secretes Se18.9 protein which binds factor $H$ that is part in regulation of the alternative complement pathway $[25,26]$.

The other factor which helps bacteria to fight phagocytosis is by damaging actions on IgG by glycosyl hydrolase Endose and endopeptidase IdeE2 $[27,28]$. Superantigens are proteins produced by some bacteria species and released into extracellular space as mature toxins. The superantigens by pass the MHC restricted antigen presentation and bind directly in a cross linking manner to MHC II molecules and TcRs [29]. This results in non-specific $\mathrm{T}$ cell proliferation and massive release of cytokines leading to inflammatory and acute phase response characterized by fever $[30,31]$. S.equi expresses four prophase encoded super antigens( toxins) they are like: SeeH, SeeI, SeeL and SeeM, from this toxins the latter three can elicit an immune response by stimulating proliferation of equine peripheral blood mono nucleated cells $[30,32,33]$.

\section{Epidemiology}

Strangle infection has been named by Schutz in 1888, but since ancient Rome strangle disease has been described by veterinarians [34]. Strangle occurs worldwide mostly in horse and rarely in donkey and mules. The outbreak of strangle disease is frequently observed on breeding farms, racing stables and horse taken to fairs and riding school, when infection is introduced by new asymptomatic horse which happen in cold weather $[2,35]$. The equine of any age may contract strangle disease, but elderly and younger equines (3 months to five years) are more susceptible, except foals less than 4 months who are protected by colostrums derived passive immunity. Elder equines may have weaker immune system and most severity affected with longer duration of the disease [36]. Horse recovered from the clinical sign of strangle disease may have persistent infection of $S$. equi equi in the guttural pouches and are source of infection. Guttural pouch is the site for colonization and integral to carrier state of S.equi equi $[37,38]$. The rupture of abscesses formed in retropharyngeal lymph nodes drains pus into the guttural pouches and horse become persistently infected carrier of strangle disease. These carriers transmit the 
origanismyo naïve horse and play an important role in disease spreading [39]. Persistent carrier (healthy animal) of S.equi equi harbor the bacteria in chondroids formatted in the guttural pouches and continue to spread the infection for prolonged periods of time [40]. Horse recover from clinical disease may have persistence infection of S.equi equi in pharynx and guttural pouches for many months [41]. Stressor factors as weaning, communal drinking sources, high population density and mobility favor the infection spreading travelling, sudden climate changes and improper nutrition facilitate the transmission of strangle $[42,43]$.

\section{Transmission}

Strangle is the most frequently diagnosed infectious disease of horses worldwide. S. equi equi is an obligate bacterium of horses and all infections are attributable to transmission from infected horse to the health one [44]. The source of infection for strangle disease are nasal and abscess discharge from infected horse [45]. Transmission of strangle among equine animals are occurs through direct and indirect ways. Direct transmission involves horse to horse contact, nose to nose touching and coughing of infected secretions into the next stall [46]. Indirect transmission involves sharing of contaminated housings, water resource, feed utensils, track and their clothing [47]. S. equi can metastasize to other organ system where it can cause abscesses in the mesentery, kidney, liver, spleen and central nervous system which called as bastard strangle [48,49]. Infected animals shed the bacteria for 2 to 3 days after the onset of fever, or 4 to 7 days after infection, and continue shedding 4 weeks after resolution of clinical signs [50]. A Strangles outbreak can last 4 to 6 months on a farm of a susceptible population with an inadequate isolation protocol [14].

\section{Equine immunity to bacteria}

The primary recognition of bacterial invaders is performed by proteins of the innate immune system of animals which called as pattern recognition receptors (PRRs) that recognize pathogen associated molecular pattern molecules. Pattern recognition receptors can be divided into secreted (Manna-binding lectins, opsonize bacteria for phagocytosis and activation of complement system), endocytic (Macrophage mannose receptor are located on the membrane of phagocytes and mediates phagocytosis and subsequent killing of ingested materials) and signal (Tolllike receptors recognize and bind different pathogen associated molecular pattern molecules (lipopolysaccride, proteoglycan and lipoteichoic acids) which used to initialize inflammation and different immune responses [51,52]. The adaptation immune response to S.equi and bacterial exotoxins is primarily executed by antibodies that opsonize whole bacteria and neutralizes exotoxins. The action of primary IgA is to block the sites of attachment of the bacteria to mucosal surfaces [53]. Natural killing cells and cytotoxic $\mathrm{T}$ cells is the defense part of host which against bacteria by directs killing action. Furthermore, immunity to extracellular bacteria and bacterial exotoxin can be conferred passively from colostrum [53].

\section{The virulence factor for strangle}

S. equi equi binds to receptors and colonize mucosal cells in a highly selective manner through their virulence factors with interact with a great variety of surface component. The adhesion of S. equi equi to host soluble components and tissues in an important step in strangle infection process [13]. The ability to interact with different substrates is likely to increase $S$. equi equi chances of surviving. $S$. equi equi have a great variety of virulence factors that interact with host tissues and components which favor bacteria colonization and growth [30].The virulence factors are listed as following:

Hyaluronic acid capsule: S. equi equi has the hyaluronic acid capsules which have high molecular weight polimer formed by residues of $\mathrm{N}$-acetyl glucosamine and glucuronic acid. The importance of this capsule is to reduce contact of bacteria with neutrophils and subsequently phagocytosis [54]. Moreover, capsule can increase the negative charge and hydro phobicity of the bacteria surface, generating a reducing environment that protects the oxygen labile proteases and toxins [55]. Therefore, without capsule, the surface protein of bacteria may aggregate, losing their configuration and functionality [56].

Fibrinogen binding proteins: Some S.equi equi can bind equine fibrinogen through different proteins or interact with fibrinogen by attachment to the C-terminal serine protease domain of equine fibrinogen to form active plasmin which hydrolyses fibrin, facilitating the spread and dispersion of bacteria on host tissues [57]. The function of plasmin is activation of complement and production of low molecule of nitrogen substances for promotion of bacterial growth [58]. M-like proteins also bind fibrinogen avidly through residues located at the extreme $\mathrm{N}$-terminus of the molecule [59]. M-like proteins: S. equi equi produces two M-like proteins: SeM, which is unique to S. equi and SzPSe, both proteins have shown a strong binding to equine fibrinogen and also antiphagocytic activity [60]. SeM is the major virulence factor and protective antigen of S. equi equi for its ability to provide phagocytosis resistance to the bacteria [61]. The antiphagocytic activity of M-like proteins are associated with their ability to inhibit deposition of the complement component $\mathrm{C} 3 \mathrm{~b}$ on the bacterial surface and also to bind fibrinogen to the $\mathrm{N}$-terminal portion of the protein, as described above, which consequently inhibits phagocytosis [55]. S. equi equi with truncated SeM has been isolated form outwardly healthy horses, therefore, this protein play an important role on bacteria virulence and seems to be related with the carrier state [39]. Se18.9 is an H factor binding protein secreted by S. equi equi that reduces the bactericidal activity of equine neutrophils and also deposition of C3 on the bacterial surface. Se18.9 is being studying for its potential to be used in immunodiagnostic and also to understand the mucosal antibody response to $S$. equi equi infection [26].

Streptolysin S: This protein is a 36 aaoligopeptide with bacteric in like cytotoxin activity responsible for the $\beta$-hemolysis [62]. To carry out its biological activity, this protein requires 
stabilization by association with a carrier protein, like albumin. The binding of the Streptolysin-albumin complex to erythrocytes causes the formation of transmembrane pores and consequently, lysis of red blood cells [63].

Pirogenic mitogens: All the pirogenic mitogens have high immune modulating capacity; they are able of binding to MHC Class-II molecules on antigen presenting cells and also to the variable region of $\beta$-chain of the T-cell receptor molecules causing a stimulation of large numbers of $\mathrm{T}$ cells and misdirection of the immune response. The result is a non-specific T-cell proliferation and proinflammatory cytokines release such as IL1, IL2, TNF- $\beta$ and IL6, responsible for triggering the acute phase of Strangles with fever, neutrophilia and fibrinogenemia [30]. Supernatant preparations of clinical isolates of $S$. equi equi elicited potent mitogenic responses from peripheral blood mononuclear cells. At least four phage associated bacterial superantigens, SeeH, SeeI, SeeL and SeeM, are known to be expressed by S. equi equi, but SeeH is inactive [64].

\section{Pathogenesis}

Strangles is clinically characterized by fever, purulent nasal discharge and abscessation of the lymphoid tissues of the upper respiratory tract [14]. Nasopharinggeal infection with S.equi equi generally follows contact with a shedding carrier horse or with an acutely infected animal [31]. After bacteria enters via nose and mouth and attaches to the crypt of the palatine and lingual tonsils, oro- and nasopharinx and lymphoid nodules [31,14]. The organism has been detected in tonsillar crypts, subepithelial follicular tissue and lymph nodes 3 hours after inoculation and the organism multiplies in the lymph nodes [65]. The visual evidence of intracellular and extracellular multiplication of $S$. Equi equi in tonsillar lymphoid tissues and lymph nodes indicates involvement of potent antiphagocytic activity and failure to innate immune defenses [12]. After only a few hours, the bacteria translocate into the local lymphatic structures where they replicate extracellular in the lymph nodes [66]. The peptidoglycan in the cell wall of $S$. equi activates the alternative complement pathway, resulting in extensive recruitment of polymorpho nuclear leukocytes to the site of infection, which is part of the basic pathology of strangles (Timoney, 2004b). The hyaluronic acid capsule of $S$. Equi equi facilitate bacteria colonization and bacteria release some toxins and enzymes which damage surrounding host cells, beginning the process of inflammation, at this stage horse show fever, nasal discharge and pharyngitis. At this time the mucosal surface is hyperaemic and histological examination reveals neutrophilic exocytosis across the epithelium with accumulation of lymphocytes, plasma cells and neutrophils in the subjacent lamina propriety [14]. The inability of the neutrophils to phagocytosis the bacteria appear to be due to the combination of the hyaluronic acid capsule, antiphagocytic M-protein and aleucocidal toxin which all are released by the bacteria [67]. Streptolysin S and Streptokinase may lead to development of abscess and lysis of damaging cell membranes and also responsible for beta hemolysis on blood agar plates [14,67].

The incubation period varies from 3 to 14 days and the first clinical sign is usually fever, followed by a serous to mucoid nasal discharge that later becomes purulent. The horse may show the signs like experience anorexia, depression, difficulty in swallowing and fever due to release of pyogenic exotoxin [33] and the peptidoglycan is considered pyrogenic by stimulating leukocytes to release pyrogenic cytokines [12]. Retropharyngeal lymph node may drain into guttural pouch and cause empyema. The retropharyngeal abscesses and guttural pouch edema may cause swelling over Viborg's triangle and may cause respiratory distress. Shedding of the bacteria starts after a latency period of 2-14 days and continues for approximately six weeks after the acute phase of disease $[12,14,60]$ although recent studies suggests that shedding may last for several months [68].

\section{Clinical sign}

The first clinical sign of strangle disease in horse is fever $\left(39^{\circ} \mathrm{C}\right)$ and upper respiratory catarrh. The fever and depression are the only symptoms in 24-48 hours before the onset of nasal discharge proceed [69]. The signs appear after an incubation period of 3 to 8 days approximately, and they generally last for 3 or 4 weeks [70]. The disease develops suddenly with complete anorexia, depression, fever, and serous nasal discharge which rapidly becomes copious and mucopurulent [71]. Retropharyngeal lymph node enlargement and submandibular enlargement may cause obstruction of oroand pharynynx with subsequent dypnea and dysphagia [36]. The most common complication is rupture of abscesses in the retro-pharyngeal lymph nodes on the roof of the nasopharynx that become inflamed and drain into overlyng guttural pouch, causing infection with empyema [72] (Figure 1\&2) Marked inflammation of the lymph nodes that drain the pharyngeal area (the primary site of infection) cause the classical equine "septic sore throat", and is manifested by grossly enlarged submandibular lymph nodes that frequently drain outside [36]. Purpurahaemorrhagica is an immune complex that may be trigger by $S$. equi equi and other streptococcal infections in horses, associated with leucocytoclasticvasculitis, edema in the head and limbs, petechial hemorrhages in mucosae, musculature and viscera, and sometimes glomerulonephritis [73]. 


\section{Current Trends in Biomedical Engineering \& Biosciences}

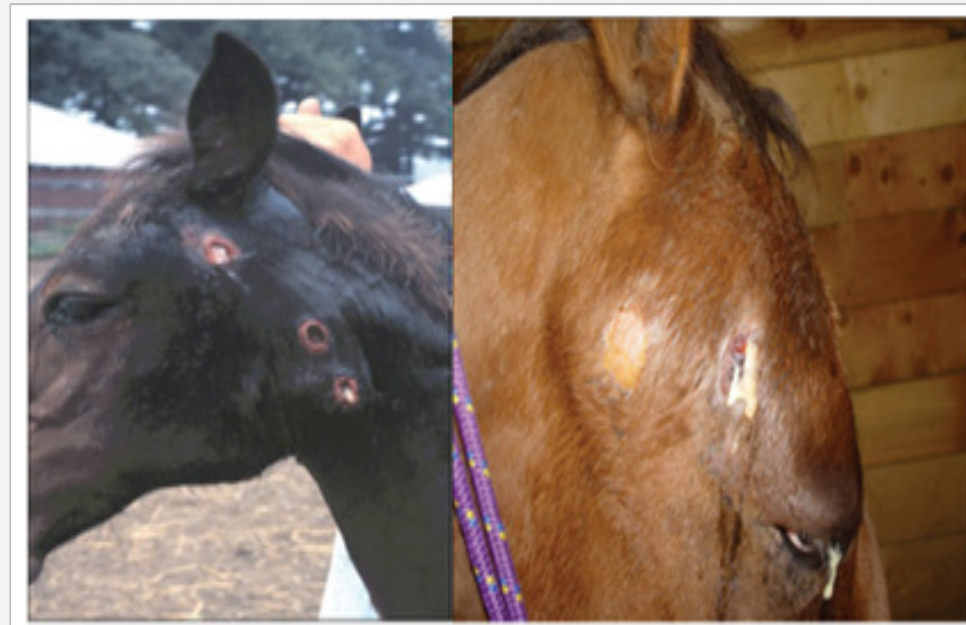

A.

B.

Figure 1: Clinical sign of strangle, A: Lymphadenopathy and abscessation occur in 7 to 10 days after infection with streptococcus equi is classical sign of strangle in naïve horses.; B: Parotid and periorbital swelling abscessation in horse with strangles.

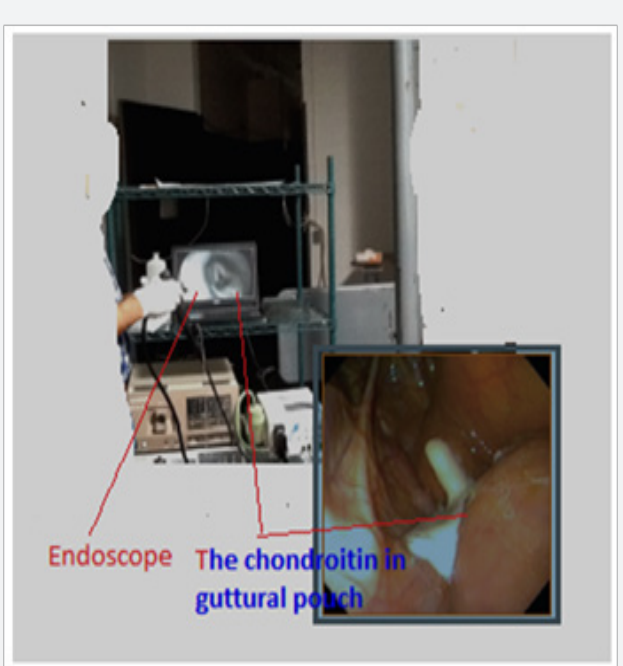

Figure 2: Endoscopy of guttural pouch of strangles convalescent for identifying asymptomatic carrier, which will have guttural pouch abnormalities such as chondroids or empyema.

Anatomical changes as infarction of the skeletal musculature, skin, gastrointestinal tract, pancreas, and lungs have been found at necropsy, also leukocytoclastic vasculitis in numerous tissues and acute coagulative necrosis. Neutrophilia with a left shift and toxic changes, hyperproteinemia, hypoalbuminemia, and high serum creatine kinase and aspartate transferase activities are frequent hematologic and serum biochemical abnormalities [74]. Immune complexes containing IgA and S. equi equi specific antigens are found after Strangles infection, as consequence of autoimmune vasculitis [73]. Metastatic brain abscesses positive for $S$. equi equi and other soft tissue lesions has been confirmed by magnetic resonance imaging in horses with Bastard Strangles [75]. Deeply located abscesses usually do not produce any welldefined clinical syndrome and are often undiagnosed. Because of the large size of many Strangles abscesses $(30 \mathrm{~cm}$ diameter or more), penetration of antibiotics is inadequate [76]. In foals with neurologic signs that had a history of Strangles or were exposure to infected horses, meningoencephalomyelitis caused by S. equi equi was reported [77]. The development of suppurative necrotic bronchopneumonia secondary to the aspiration of pus from ruptured abscesses or metastatic infection of the lungs is another reported complication [74].

\section{Histopathological sign}

The SeM inhibition of C3 complement deposition on the bacterium avoids opsonisation, decreasing the neutrophil chemotaxis and microorganism clearance, therefore the bacteria spread to the submandibular and retropharyngeal lymph 
nodes in few hours [78]. Histologically, lymphoid necrosis and massive neutrophils infiltration can be observed and by gram staining streptococci can be seen in necrosis areas, most of bacteria are not phagocytosed by neutrophils [14].In guttural pouches many proteins mediate the attachment of $S$.equi equi to mucosal surface. In the epithelium the wide distribution of glucosaminoglycanes seems to be deteriminant of S.equi equi adhesion and may facilitate $S$. equi equi colonization through SeM [79].

The preference of S.equi equi for guttural pouchs may indicate by presence of a great variety of glucosaminoglycanes such as chondroitinsulphate B, heparin and heparin sulphate in guttural pouch which have great role on pathogenesis of strangles infection [79]. Most of the abscesses are located on the abdomen and thorax [80]. The S. Equi equi M-protein may trigger the immune complex disease purpura haemorrhagica inducing the formation of complexes that bind to the $\beta 2$-integrins of host neutrophils, leading to their activation and subsequent realise of heparin binding protein, an inflammatory mediator that induces generalized vasculitis, oedema and toxic shock which is frequently fatal [81].

\section{Diagnosis}

The diagnosis of strangles based on the history and clinical signs, diagnostic should be confirmed by culture of nasal swabs, washes, or lymph nodes aspirates and PCR for the identification the bacterium [82]. The culture of nasal swabs, nasal washes and aspirated pus from abscesses are remains gold standard. Nasal washes are more effective than swabs in detection of small numbers of bacteria. The washes can take sample from a greater surface area. The technique is although simple [14]. The encapsulated bacteria forms a honey colored mucoid colony with a zone of beta-hemolysis on blood agar, and does not ferment lactose, trehalose or sorbitol, these characteristics differentiate S. equi equi from S. equi zooepidemicus [83], although, it is important to confirm the subsp. by PCR [23]. S.equi is differentiated from $\mathrm{S}$. zooepidemicus using the aspect that $\mathrm{S}$. zooepidemicus capacity to ferment sorbitol and lactose $[22,83]$. Polymerase chain reaction (PCR) is a method to detect DNA sequence of SeM of bacteria. SeM is the gene for the antiphagocytic M-protein of S. equi, the forward primer of bacterial DNA ASW73 (50-CAG AAAACT AAG TGC CGGTG-30) and the reverse primer ASW74 (50-ATTCGG TAA GAGCTT GAC GC-30) were used to amplify541 base pair of the 50 region of the SeM gene unique to $\mathrm{S}$ equi, as described previously [84].

The gene is also found in S. zooepidemicus but there is no evidence that the M-protein is expressed by that bacterium [14]. PCR is also useful to detect asymptomatic carriers and ascertain the success of elimination from guttural pouch [14]. Polymerase chain reaction (PCR) does not distinguish between live and dead organisms. PCR is approximately 3 times more sensitive than culture [85]. ELISA does not predict carrier status after a strangles outbreak, but it can measures the level of SeM antibody in serum of equine animals sand also it can be helpful in diagnosing recent infection or determine the need for a booster vaccine [83]. PCR increases the carrier detection rate because it is three times more sensitive than cultures and detects the DNA sequence of S.c equi equi SeM gene, therefore positive test cannot correlate with an active infection [13].

Persistent carriers of S. equi equi may be identified by culture and PCR testing of lavage fluid from the nasopharynx or guttural pouches and nasopharynx swabs after recovery from acute disease and at postmortem examination [85]. Gutturalpouch and upper airways endoscopy with subsequent culture and PCR testing to detect $\mathrm{S}$. equi equi remains the most accurate method available for the identification of persistent carriers [83]. Other diagnostic as pharyngeal radiography and lymph node ultrasonography may help to have an accurate diagnosis [36]. Strangles should be differentiated clinically from other upper respiratory tract diseases of horses. Chronic weight loss due to metastatic infection should be differentiated from equine infectious anemia, parasitism, inadequate nutrition, and neoplastic [86].

\section{Treatment}

Treatment of an animal in the early stages of the disease is usually effective and is not associated with side effects [87]. The use of antimicrobials is also controversial. S. equi equi is highly susceptible to penicillin G, which is recommended at $22,000 \mathrm{IU} / \mathrm{kg}$ in early stages [23]. The application of penicillin after abscesses draining speed the recovery and prevents complications. The organism is also susceptible to ampicilin, ceftiofur, erythromycin, rifampicin, tetracycline; all of them are effective in treating field cases [74]. For horses that have developed lymph node abscessation are antibiotic therapy is probably contraindicated. Treatment only prolongs the enlargement and eventual rupture of lymph node abscesses. The infection and abscessation will return when the treatment is discontinued [14]. Non-steroid anti-inflammatory drugs to reduce fever and pain are also useful, as resting in a warm setting and soft-moist feeding [76]. Asymptomatic guttural pouch carriers should be tested for Strangles by PCR, and also by endoscopy. In the cases of guttural pouch empyema, these should be lavage daily with 1 to 2 liters of isotonic saline or polyionic fluids for 2 to 3 days following evidence of resolution. In horses with lymph nodes inflammation of the head and neck or with internal abscesses, high doses of beta-lactam antimicrobials and drainage of abscesses are recommended. In animals with dysphagia, intravenous fluids and nasogastric feeding may be necessary [14].

\section{Control and prevention}

Strangle outbreaks are more frequently when new animals, incubating the disease or recovering and still shedding the organism, is introduced. The best way to prevent an outbreak of strangles is keeping animals in hygienic and isolating infected 
animals. The horse should be isolated for 3 weeks [88].The younger horses should be kept separately from older horses, where the most important thing is to keep horses in competition away from younger horses. The stable should be supplied with good equipment for hand washing with clean warm water, soap and a clean towel [69]. Strangles has a very contagious nature, which makes the control of spread among horses on farms very difficult. Horses with strangles as well as their environment should be isolated [23]. Rectal temperature should be taken at least once daily. If a horse with fever is discovered it should be isolated immediately. To find horses that are infectious after clinical recovery 3 sequential nasal swabs at weekly intervals should be taken [14].

In generally, The best biosecurity measures for prevention of strangle disease are like Quarantine new horse arrivals, avoid mingling with other horses at shows and other events, avoid sharing water buckets and equipment, vaccinate to reduce the severity and spread of strangles, provide clean, dry housing and practice good sanitation. In a group of infected horses; all movements should be stopped and an infected quarantine area should be separated from both clean and contaminated area with strict hygienic activities [89]. Infected horses should be isolated and treated, newly introduced horses should be quarantined for three weeks and observe for signs of strangles, horses with elevated temperature should have nasopharyngeal or guttural pouch swab cultures, recovered horses never be mingled with susceptible horses for a period of several months and infection status should be determined by three PCR examination and cultures at weekly interval [90].

All potential sources of fomites including pails, brooms, housings, feed utensils, water troughs and pasture and grooming brushes should be thoroughly cleaned and disinfected; people who care of infected horses must avoid contact with susceptible horses if not they must wear protective boots and clothes. Pastures on which infected horses have stayed should rest for four weeks [91]. Vaccination is one of the important control and prevention method for strangles [86]. With strangles, vaccination will most likely reduce the severity of disease in the majority of horses infected after they are vaccinated. Available vaccines can be administered by intramuscular, intravenous, subcutaneous and intranasal routes. Extract vaccine (m Protein rich extracts) and live attenuated vaccines are widely used [14]. Vaccination is generally not recommended during an outbreak of strangles. If there are horses on the farm with no clinical signs of infection (Fever, nasal discharge) and no known contact with sick horses, vaccination may be considered [91]. Vaccination of horses recently exposed to strangles (That have high antibody levels) may result in purpurahemorrhagica.

Vaccination is only recommended in healthy horses with no fever or nasal discharge [92]. Naïve horses and foals should be vaccinated with extract vaccines IM or IV or subcutaneously at an interval of two weeks with two to three doses. It elicits serum antibody responses within seven days [91]. Horses can also be vaccinated by live attenuated vaccines through intranasal or submucosal routes which stimulate mucosal and systemic antibodies response. Booster doses are given once annually [14]. Vaccination of brood mares one month before foaling increases colostral IgG antibodies and presumably serum and mucosal immunoglobulin concentration in their foals [93].

\section{Conclusion and Recommendation}

Strangles is an infectious, highly contagious disease of equine animals which characterized by abscessation of the lymphoid tissue of the upper respiratory tract [94]. It is cause by Streptococcus equi subsp. equi ( $S$. equi) which belonging to the genus Streptococcus [95]. Strangle disease have high morbidity rate, but low mortality rate [96-100]. The severity of strangle disease varies greatly with clinical manifestation of upper respiratory system within fatal complication like acute dyspnoea, dysphagia, internal lymph node abscessation and immune mediated response. Streptococcus equi is highly resistance to phagocytosis due to its hyaluronic acid capsule which mask binding sites for complement factor and reduces risk of phagocytosis [101-103]. Younger and elder equines are more susceptible to strangle disease, due to they have weak immunity. The major clinical sign of strangle are start with fever, depression, slight cough, clear water nasal discharge that quickly changes to thick and yellow, dysphagia, loss of appetite and enlargement of lymph node in lower jaw. The most common diagnosis of strangle is by PCR, serology and microbial culturing. Treatment of strangle in acute phase is usually effective, but in the chronic form it is not effective to treat animals with antimicrobial. The best treatment in chronic phase is by ravaging pus from guttural pouch [104,105]. To eradicate and control of strangle disease the environment and animals should be kept in hygienic condition and the animals must be vaccinated.

Depending on above conclusion the following there commendations will be forwarded. The disease animal should be treated immediately and isolate from healthy animals. The puss should be drainage and clean with antiseptics, the environment should have to kept in hygienic state. The government should have to install the vaccination and other infrastructure to veterinary sector. The veterinary ministry should have to spread the drug unto the sector of animals healthy and the clinician should have to keep and follow the disease equine. The community should have to keep their environment in hygienic state and the owner ought to have to isolate their diseased horse for healthy equines. Horses should be isolated to stop the spread of strangles. Consult with your veterinarian concerning the best treatment for your horse. An animal with an unknown health history should be isolated from normal horses for a month, which is the usual time required for full recovery. Treatment focuses on supportive care of the animal by keeping the horse warm and dry, providing soft food, monitoring horse's temperature, applying hot compresses to abscessed lymph nodes to promote rupture and drainage 
and Flush draining tracks with dilute povidone-iodine solution (Betadine).

\section{References}

1. Martuzzi F, Catalano AL, Sussi C (2001) Characteristics of horse meat consumption and production in Italy. Annalidella Facoltà di Medicina Veterinaria 21: 213-233.

2. Pritchard JC, Lindberg AC, Main DDT, Whay HR (2005) Assessment of the welfare of working horses, mule and donkeys, using health and behavior parameters. Prev Vet Med 69(3-4): 265-283.

3. Anon (2014) Federal democratic Republic of Ethiopia. Central Statistical Agency: Agricultural Survey 2013/14. Statistical Bulletin, p. 573.

4. Central Statistical Agency (2016) Agricultural survey. Report on livestock, poultry and bee hives population, private peasant holdings. Addis Ababa, Ethiopia, p. 17.

5. Garuma S, Lemecha F, Sisay A, Jemal E (2007) Study on gender distribution of ownership of animal-drawn carts and its effect on women's life in Adami Tulu and Dugda Bora districts. In: Draught Animal News, Ed: Centre for Tropical Veterinary Medicine (CVTM), University of Edinburgh, Edinburgh, Scotland, pp. 29-34.

6. Gebreab F (1997) Diseases and health problems of donkeys abroad. In: The Professional Handbook of the Donkey, Ed: E. Svendsen, Whittet Books Ltd, UK, pp. 207-226.

7. Asmamaw K, Alemayehu T, Alemayehu R, Bojia E (2014) A preliminary study of the socioeconomic contribution of working equids in Dalocha District, Southern Ethiopia. In: Seventh International Colloquium on Working Equids, Ed: J Wade, World Horse Welfare, Norfolk, UK, p. 27.

8. Neamat Allah ANF, El Damaty HM (2016) Strangles in Arabian horses in Egypt: Clinical, epidemiological, hematological, and biochemical aspects. Vet World 9(8): 820-826.

9. Rush B, Mair T (2004) Equine respiratory diseases: Blackwell Science Ltd.

10. Davis EG (2007) Respiratory Infections. In: Sellon DC (Ed.), Equine Infectious Diseases. Saunders, Philadelphia, USA, pp. 1-13.

11. Wood JL, Newton JR, Chanter N, Mumford JA (2005a) Association between respiratory disease and bacterial and viral infections in British racehorses. Journal of clinical microbiology 43(1): 120-126.

12. Timoney JF (2004a) The pathogenic equine streptococci. Vet Res 35(4): 397-409.

13. Paillot R, Darby AC, Robinson C, Wright NL, Steward KF, et al. (2010a) Identification of three novel superantigen-encoding genes in Streptococcus equi subsp. zooepidemicus, szeF, szeN, and szeP. Infection and immunity 78(11): 4817-4827.

14. Sweeney CR, Timoney JF, Newton RJ, Hines MT (2005) Streptococcus equi Infections in Horses: Guidelines for Treatment, Control, and Prevention of Strangles. J Vet Intern Med 19(1): 123-134.

15. Whelchel DD, Chaffin MK (2009) Sequelae and complications of Streptococcus equi sub species equi infections in the horse. Equine Veterinary Education 21(3): 135-141.

16. Cullinane AA, Barr B, Bernard W (2006) Infectious diseases. In: Snyder JR (Ed), The Equine Manual. $2^{\text {nd }}$ edn. Ch. 1. W. B. Saunders, Edinburgh, Scotland, UK, pp. 1-111.

17. Khoo LL, Maswati MA, Roseliza R, Rosnah Y, Saifu Nazri R, et al. (2011) Isolation of Streptococcus equi during strangles survellance in Peninsular Malaysia. Malays J Vet Res 2(2): 27-32.

18. Mallicote M (2015) Update on Streptococcus equi subsp equi infections. Vet Clin North Am Equine Pract 31(1): 27-41.
19. Robinson C, Steward KF, Potts N, Barker C, Hammond TA, et al. (2013) Combining two serological assays optimises sensitivity and specificity for the identification of Streptococcus equi subsp. equi exposure. Vet J 197(2): 188-191.

20.Waller AS (2014) New Perspectives for the diagnosis, control, treatment, and prevention of strangles in horses. Vet Clin North Am Equine Pract 30(3): 591-607.

21. Corinne RS (2010) Strangles, Streptoccocus equi infection in horses. Journal of equine veterinary education 8(6): 317-322.

22. Quinn PJ, Markey BK, Leonard FC, Fitz Patrick ES, Fanning S, et al. (2011) Veterinary microbiology and microbial disease. ( $2^{\text {nd }}$ edn), $p$. 928.

23. Taylor SD, Wilson DW (2006) Streptococcus equi subsp. Equi (Strangles) Infection. Clinical Techniques in Equine Practice 5(3): 211-217.

24. Lewis MJ, Meehan M, Owen P, Woof JM (2008) A common theme in interaction of bacterial immunoglobulin-binding proteins with immunoglobulins illustrated in the equine system. J Biol Chem 283(25): 17615-17623.

25. Kopp A, Hebecker M, Svobodová E, Józsi M (2012) Factor h: a complement regulator in health and disease and a mediator of cellular interactions. Biomolecules 2(1): 46-75.

26. Tiwari R, Qin A, Artiushin S, Timoney JF (2007) Se18.9, an antiphagocytic factor $\mathrm{H}$ binding protein of Streptococcus equi. Vet Microbiol 121(1-2): 105-115.

27. Flock M, Frykberg L, Skold M, Guss B, Flock JI (2012) Antiphagocytic function of an IgG glycosyl hydrolase from Streptococcus equi subsp. equi and its use as a vaccine component. Infect immune 80(8): 29142919.

28. Hulting G, Flock M, Frykberg L, Lannergard J, Flock JI, et al. (2009) Two novel IgGendopeptidases of Streptococcus equi. FEMS Microbiol Lett 298(1): 44-50.

29. Proft T, Fraser JD (2003) Bacterial superantigens. Clin Exp Immunol 133(3): 299-306.

30. Paillot R, Robinson C, Steward K, Wright N, Jourdan T, et al. (2010b). Contribution of each of four Superantigens to Streptococcus equiinduced mitogenicity, gamma interferon synthesis, and immunity. Infection and immunity 78(4): 1728-1739.

31. Timoney JF (2004b) Streptococcus. In: Gyles CL (Ed.), Pathogenesis of bacterial infections in animals. ( $3^{\text {rd }}$ edn), Iowa state university publishing, USA, pp. 23-42.

32. Proft T, Webb PD, Handley V, Fraser JD (2003) Two novel superantigens found in both group A and group C Streptococcus. Infect immun 71(3): 1361-1369.

33. Artiushin SC, Timoney JF, Sheoran AS, Muthupalani SK (2002) Characterization and immunogenicity of pyrogenic mitogens SePE-H and SePE-I of Streptococcus equi. Microb pathog 32(2): 71-85.

34. Pelagonius (1980) Ars Veterinaria. In: Fischer KD (Eds) Pelagoniiarsveterinaria. Leipzig, Germany, pp. 13-16.

35. Fairfield B (2013) Strangles, Current thoughts on management. Journal of internal medicine.

36. Hardy J, Léveilé R (2003) Diseases of the guttural pouches. Vet Clin North Am Equine Pract 19(1): 123-158.

37. McGorum Di Bruce C, Dixon Padraic M, Robinson N (2007) Equine Respiratory Medicine and Surgery. Saunders Elsevier pp. 677-705.

38. Timoney JF (2000) Strangles. Journal of Equine Veterinary Science 20(9): 572.

39. Chanter N, Talbot NC, Newton JR, Hewson D, Verheyen K (2000) 
Streptococcus equi with truncated M-proteins isolated from outwardly healthy horses. Microbiology 146 (Pt 6): 1361-1369.

40. Verheyen K, Newton JR, Talbot NC, de Brauwere MN, Chanter N (2000) Elimination of guttural pouch infection and inflammation in asymptomatic carriers of Streptococcus equi. Equine Vet J 32(6): 527 532 .

41. Hansen KA (2000) Bacteriological Laboratory Techniques. (1 ${ }^{\text {st }}$ edn), USA, pp: 121-122.

42. Timoney JF, Kumar P (2008) Early pathogenesis of equine Streptococcus equi infection (strangles). Equine Vet J 40(7): 637-642.

43. Holcombe SJ, Jackson C, Gerber V, Jefcoat A, Berney C, et al. (2001) Stabling is associated with airway inflammation in young Arabian horses. Equine Vet J 33(3): 244-249.

44. Waller AS (2013) Strangles: Taking steps towards eradication. Veterinary Microbiology, pp. 1-11.

45. Jacobs AA, Goovnerts D, Nuijten JP (2000) Submucosal Vaccination with a Live Attenuated S.equiequi. Veterinary Records 147: 563-567.

46. Stringer A (2009) Strangles, epidemiology and control. Tay Valley Veterinary Center 1: 4-5.

47. Reed SM, Bayly WM, Sellon DC (2010) Equine Internal Medicine. (3 ${ }^{\text {rd }}$ edn), St. Louis, Saunders, USA.

48. Hanche Olsen S, Ottesen N, Larsen H, Fintl C (2012) Brain Abscess in a 4-Month-Old Filly: A Case Report. J Equine Vet Sci 32(1): 1-4.

49. Ainsworth DM, Hackett RP (2004) Disorders of the respiratory system. In: Reed SM (Ed.), Equine Internal Medicine. $2^{\text {nd }}$ edn, St. Louis Missouri: Saunders, Missouri, USA, pp. 289-353.

50. Newton JR, Wood JL, Dunn KA, De Brauwere MN, Chanter N (1997) Naturally occurring persistent and asymptomatic infection of the guttural pouches of horses with Streptococcus equi. Vet Rec 140(4): 84-90.

51. Brown GD (2006) Dectin-1: a signalling non-TLR pattern-recognition receptor. Nat Rev Immunol 6(1): 33-43.

52. Medzhitov R, Janeway C (2000) Innate immunity. N Engl J Med 343(5): 338-344.

53. Giguere S, Prescott JF (2000) Equine immunity to bacteria. Veterinary clinics of North America: Equine practice 16(1): 29-47.

54. Kyossev Z, Weigel PH (2007) An enzyme capture assay for analysis of active hyaluronan synthases. Anal Biochem 371(1): 62-70.

55. Cole JN, Pence M, Hollands A, Gallo RL, Walker MJ (2010) M protein and hyaluronic acid capsule are essential for in vivo selection of covRS mutations characteristic of invasive serotype M1T1 group A streptococcus. MBio 1(4)

56. Harrington DJ, Sutcliffe IC, Chanter N (2002) The molecular basis of Streptococcus equi infection and disease. Microbes infect 4(4): 501510.

57. Davidson A, Traub Dargatz JL, Magnuson R, Hill A, Irwin V, et al. (2008) Lack of correlation between antibody titers to fibrinogen-binding protein of Streptococcus equi and persistent carriers of strangles. J Vet Diagn Invest 20(4): 457-462.

58. Meehan M, Lynagh Y, Woods C, Owen P (2001) The fibrinogen-binding protein (FgBP) of Streptococcus equi subsp. equi additionally binds IgG and contributes to virulence in a mouse model. Microbiology 147(Pt 12): 3311-3322.

59. Meehan M, Lewis MJ, Byrne C, Hare OD, Woof JM, et al. (2009) Localization of the equine IgG-binding domain in the fibrinogenbinding protein (FgBP) of Streptococcus equi subsp. equi. Microbiology
155(Pt 8): 2583-2592.

60. Timoney JF, Mukhtar MM (1993) The protective M proteins of the equine group C streptococci. Vet Microbiol 37(3-4): 389-395.

61. Anzai T, Kuwamoto Y, Wada R, Sugita S, Kakuda T, et al. (2005) Variation in the N-terminal region of an M-like protein of Streptococcus equi and evaluation of its potential as a tool in epidemiologic studies. Am J Vet Res 66(12): 2167-2171.

62. Hashikawa S, Iinuma Y, Furushita M, Ohkura T, Nada T, et al. (2004) Characterization of group $\mathrm{C}$ and $\mathrm{G}$ streptococcal strains that cause streptococcal toxic shock syndrome. J Clin Microbiol Ene 42(1): 186192.

63. Nobbs AH, Lamont RJ, Jenkinson HF (2009) Streptococcus adherence and colonization. Microbiol Mol Biol Rev 73(3): 407-450.

64. Alber J, El Sayed A, Estoepangestie S, Lämmler C, Zschöck M (2005) Dissemination of the superantigen encoding genes seeL, seeM, szeL and szeM in Streptococcus equi subsp. equi and Streptococcus equi subsp. zooepidemicus. Vet Microbiol 109(1-2): 135-141.

65. McGorum Di Bruce C, Dixon Padraic M, Robinson N (2007) Equine Respiratory Medicine and Surgery. Saunders Elsevier , USA, pp. 677705.

66. Timoney JF, Kumar P (2008) Early pathogenesis of equine Streptococcus equi infection (strangles). Equine Vet J 40(7): 637-642.

67. Flanagan J, Collin N, Timoney J, Mitchell T, Mumford JA, et al. (1998) Characterization of the haemolytic activity of Streptococcus equi. Microb Pathog 24(4): 211-221.

68. Gröndahl G, Aspán A, Båverud V, Ljung H, Riihimäki M (2012) When should ideally screening begin to declare freedom of strangles in horses after their clinical recovery? In: Proceedings of Havemeyer Foundation Workshop on Getting to Grips with Strangles and other Streptococcal Diseases, Lexington, Kentucky, USA.

69. SVA (2013) Kvarka.

70. Timoney JF (2000) Strangles. Journal of Equine Veterinary Science 20(9): 572.

71. Robinson N (2009) Current therapy in equine medicine. ( $6^{\text {th }}$ edn), Saunders Elsevier, St. Louis Mo, USA, pp. 288-292.

72. Safia B (2006) Handbook of Equine Respiratory Endoscope. ( $1^{\text {st }}$ edn), Saunders Ltd, UK.

73. Heath SE, Geor RJ, Tabel H, McIntosh K (1991) Unusual patterns of serum antibodies to Streptococcus equi in two horses with purpura hemorrhagica. J Vet Intern Med 5(5): 263-267.

74. Dixon PM (2008) Strangles complications and clinical solutions. Exposure Veterinary Journal 197: 188-191.

75. Spoormakers TJ, Ensink JM, Goehring LS, Koeman JP, TerBraake F, et al. (2003) Brain abscesses as a metastatic manifestation of strangles: symptomatology and the use of magnetic resonance imaging as a diagnostic aid. Equine Vet J 35(2):146-151.

76. Timoney JF (1993) Strangles. Vet Clin North Am: Equine Prat 9(2): 365-374.

77. Finno C, Pusterla N, Aleman M, Mohr FC, Price T, et al. (2006) Streptococcus equi meningoen cephalomyelitis in a foal. J Am Vet Med Assoc 229(5):721-724.

78. Hinchkliff K, Kaneps A, Geor R (2004) Equine Sports Medicine and Surgery. Elsevier, USA.

79. Arias M, Magi GE, Parillo F, Cutteri V, Renzoni G (2008) Evaluation of a three-dimensional culture of equine guttural pouches to study interactions between Streptococcus equi and mucopolysaccharides: 
preliminary results. En: Book of Abstracts: ESPV 26th Annual Meeting. Zagreb, Croatia.

80. Slater JD (2003) Strangles, bastard strangles, vives and glanders: archaeological relics in a genomic age. Equine Vet J 35(2): 118-120.

81. Kaese HJ, Valberg SJ, Hayden DW, Wilson JH, Charlton P, et al. (2005) Infarctive purpura hemorrhagica in five horses. J Am Vet Med Assoc 226(11): 1893-1898.

82. Laus F, Preziuso S, Spaterna A, Beribe F, Tesei B, et al. (2007) Clinical and epidemiological investigation of chronic upper respiratory diseases caused by beta haemolytic Streptococci in horses. Comp Immunol Microbiol Infect Dis 30(4): 247-260.

83. Lanka S, Borst LB, Patterson SK, Maddox CW (2010) A multiphasic typing approach to subtype Streptococcus equi subspecies equi. J Vet Diagn Invest 22(6): 928-936.

84. Kelly C, Bugg M, Robinson C, Mitchell Z, Davis Poynter N, et al. (2006) Sequence variation of the SeM gene of Streptococcus equi allows discrimination of the source of strangles outbreaks. J Clin Microbiol 44(2): 480-486.

85. Newton JR, Verheyen K, Talbot NC, Timoeny JF, Wood JLN, et al. (2000) Control of strangles outbreaks by isolation of guttural pouch carriers identified using PCR and culture of Streptococcus equi. Equine veterinary journal 32(6): 515-526.

86. Smith PB (2009) Large animal internal medicine. (4 $4^{\text {th }}$ edn), Mosoby, UK, pp: 533-553.

87. Davidson A, Traub Dargatz JL, Magnuson R, Hill A, Irwin V, et al. (2008) Lack of correlation between antibody titers to fibrinogen-binding protein of Streptococcus equi and persistent carriers of strangles. J Vet Diagn Invest 20(4): 457-462.

88. Sellon DC, Long MT (2007) Equine Infectious Diseases. St. Louis: Saunders.

89. Chauhan SVH (2001) Pathology of Infectious Diseases of Domestic Animals. (1 $1^{\text {st }}$ edn). Charbagh, India, pp. 124-125.

90. Lefevre CP, Blancou J, Chermette R, Uilenberg G (2010) Infectious diseases of Livestocks. (1 $1^{\text {st }}$ edn), Paris, France, pp. 909-915.

91. Jennifer C (2013) Strangles in horses. The Daily Veterinary Journal 29: 838-894.

92. Rose FR, Hodgson RD (2000) Manuals of Equine Practice. (2 $\left.{ }^{\text {nd }} e d n\right)$, Saunders, USA, pp: 205-206
93. Rao GD (2010) A text book of systemic pathology on domestic animals. ( $1^{\text {st }}$ edn), pp. 102-103.

94. Anzai T, Timoney JE, Kuwamoto Y, Wada R, Oikawa M, et al. (2002) Polymerase chain reaction-restriction fragment length polymorphism analysis of the SzP gene of Streptococcus zooepidemicus isolated from the respiratory tract of horses. Am J Vet Res 63(9): 1298-1301.

95. Anzai T, Walker JA, Blair MB, Chambers TM, Timoney JF (2000) Comparison of the phenotypes of Streptococcus zooepidemicus isolated from tonsils of healthy horses and specimens obtained from foals and donkeys with pneumonia. Am J Vet Res 61(2): 162-166.

96. Natarajan D, Langohr I (2003) Purdue University Animal Disease Diagnostic Laboratory Newsletter.

97. Sponseller BT, Valberg SJ, Tennent Brown BS, Foreman JH, Kumar P, et al. (2005) Severe acute rhabdomyolysis associated with Streptococcus equi infection in four horses. J Am Vet Med Assoc 227(11): 1800-1807.

98. Timoney JF, Artiushin SC, Boschwitz JS (1997) Comparison of the sequences and functions of Streptococcus equi M-like proteins SeM and SzPSe Infect Immunol 65(9): 3600-3605.

99. Timoney JF, Yang J, Liu J, Merant C (2008) IdeE reduces the bactericidal activity of equine neutrophils for Streptococcus equi. Vet Immunol Immunopathol 122(1-2): 76-82.

100. Votava M, Handbook of bacterial adhesion: Principles, methods and applications Y.H. Humana Press Inc., Totowa, New Jersey, USA, p. 200.

101. Walker RL, Runyan CA (2003) Identification of variations in SzP proteins of Streptococcus equi subspecies zooepidemicus and the relationship between protein variants and clinical signs of infection in horses. American journal of veterinary research 64(8): 976-981.

102. Watson ED (2000) Post-breeding endometritis in the mare. Anim Reprod Sci 60-61: 221-232.

103. Webb K, Jolley KA, Mitchell Z, Robinson C, Newton JR, et al. (2008) Development of an unambiguous and discriminatory multilocus sequence typing scheme for the Streptococcus zoo epidemicus group. Microbiology 154(10): 3016-3024.

104. Wilson RT (1995) The Tropical Agriculturalist, Livestock production systems, Distribution and Importance of livestock in the tropics. CTA Macmillan, London, p. 5.

105. Wood JL, Newton JR, Chanter N, Mumford JA (2005b) Inflammatory airway disease, nasal discharge and respiratory infections in young British racehorses. Equine Vet J 37(3): 236-242.

\begin{tabular}{l} 
Your next submission with Juniper Publishers \\
will reach you the below assets \\
- Quality Editorial service \\
- Swift Peer Review \\
- Reprints availability \\
- E-prints Service \\
- Manuscript Podcast for convenient understanding \\
- Global attainment for your research \\
- Manuscript accessibility in different formats \\
( Pdf, E-pub, Full Text, Audio) \\
- Unceasing customer service \\
Track the below URL for one-step submission \\
https://juniperpublishers.com/online-submission.php \\
\hline
\end{tabular}

